\title{
PLANOWANIE TRASY BEZZALOGOWEGO STATKU POWIETRZNEGO PODCZAS LOTU NAD TERENEM Z PRZESZKODAMI
}

\begin{abstract}
Pomimo znacznych postępów w tematyce zwiększenia autonomiczności bezzałogowych obiektów latającego, pozostaje jeszcze wiele problemów do rozwiązania, jednym $\mathrm{z}$ nich to problem autonomicznego planowania trasy. Mimo iż ten problem jest obecnie przedmiotem badań licznych ośrodków badawczych na świecie, nadal jednak nie opracowano uniwersalnego sposobu planowania trasy, gdyż jest to związane nie tylko z właściwościami danego obiektu, ale również z realizowaną misją. W niniejszym artykule omówiono problem planowania trasy dla bezzałogowego statku powietrznego podczas lotu nad terenem z przeszkodami. Opracowany został algorytm do wyznaczania trasy uwzględniający ograniczenia nałożone przez właściwości obiektu latającego, ukształtowanie terenu, strefy zakazane oraz maksymalny dopuszczalny pułap lotu. Ponadto zaproponowano metodę poszukiwania quasi-optymalnej trajektorii w przypadku większej liczby przeszkód. Przeprowadzono szereg badań symulacyjnych weryfikujących poprawność działania opracowanego algorytmu.
\end{abstract}

Słowa kluczowe: BSP, planowanie trasy, omijanie przeszkód

\section{Wstęp}

Ważnym etapem podczas planowanie misji bezzałogowego statku powietrznego jest planowanie jego trajektorii. Planowanie trajektorii oznacza wyznaczenie punktów trasy, po których ten obiekt ma lecieć. Większość bezzałogowych statków powietrznych jest zdalnie sterowana, lub też planowana jest ich trasa na ziemi jeszcze przed startem. Istnieje również możliwość wysyłania punktów trasy podczas lotu. Jednak coraz częściej spotyka się bezzałogowe aparaty latające z pewnym stopniem autonomiczności dotyczącym również planowania trasy. Możliwość autonomicznego wyznaczenia trasy przez obiekt latający odciąża operatora (zwłaszcza podczas lotu nad skonfigurowanym terenem, gdzie dochodzi problem omijania przeszkód) oraz umożliwia samodzielne po-

\footnotetext{
${ }^{1}$ Autor do korespondencji/corresponding author: Fatina Liliana Basmadji, Politechnika Rzeszowska, e-mail: basmadji@prz.edu.pl

2 Jan Gruszecki, Politechnika Rzeszowska, e-mail: awionjgr@prz.edu.pl
} 
dejmowanie decyzji nawigacyjnych poprzez obiekt w nagłych przypadkach takich jak podczas awarii systemu transmisji.

Problem ten jest obecnie przedmiotem badań licznych ośrodków badawczych na świecie. Jako przykład można podać pracę [3] gdzie skorzystano z metody optymalizacji rojem cząstek do wyznaczenia trasy bezzałogowego obiektu latającego w środowisku trójwymiarowym. Kolejny ciekawy pomysł można znaleźć w pracy [2], gdzie chcąc wykonywać manewry, w podobny sposób jak pilot, zastąpiono model zachowania się operatora jakim jest model Rasmussena rozmytym programowaniem dynamicznym oraz algorytmem $\mathrm{A}^{*}$. W pracy [4] przedstawiono nowatorskie rozwiązanie optymalizacji trasy bezzałogowego obiektu latającego, korzystając z algorytmu Dijkstry oraz teorii sztucznego pola potencjałowego. Użycie optymalizacji metodą szybkiego poszukiwania drzewa losowego (RRT), w połączeniu z planowaniem trasy na podstawie krzywych Beziera, można znaleźć w pracy [5]. Jak widać można znaleźć wiele ciekawych pomysłów na rozwiązanie problemu planowania trasy BSP, nadal jednak nie opracowano uniwersalnego sposobu planowania trasy, gdyż jest o związane nie tylko z właściwościami danego obiektu, ale również z realizowaną misją. Planowanie trajektorii obiektu latającego jest typowym zagadnieniem optymalizacji. W niniejszej pracy jako kryterium przyjęto długość trasy. Najkrótsza trasa pomiędzy dwoma zadanymi punktami podczas lotu w terenie z przeszkodami nie zapewnia braku przeszkód na drodze przelotu. Dlatego, podczas wyznaczenia wskaźnika jakości należy wziąć pod uwagę między innymi ukształtowanie terenu. Kolejną rzeczą jaką należy uwzględnić jest możliwość zrealizowania określonej trajektorii przez dany obiekt latający. Następnym problemem jest orientacja przestrzenna statku powietrznego. Trasa pomiędzy dwoma punktami będzie różniła się w zależności od początkowej orientacji przestrzennej statku powietrznego oraz od docelowego kursu w punkcie końcowym.

\section{Problemy związane z wyznaczaniem trasy BSP}

Podczas planowania trajektorii bezzałogowego obiektu latającego należy wziąć pod uwagę następujące informacje:

- przeszkody stałe znajdujące się w obszarze, w którym ten obiekt wykonuje lot (np. konfiguracja terenu),

- ewentualne przeszkody które mogą się pojawić na drodze obiektu (np. inny obiekt latający),

- strefy w których lot jest zakazany (No Fly Zone),

- maksymalną dopuszczalną wysokość lotu,

- początkowy kurs oraz docelowy kurs obiektu latającego.

Rozpoczynając od przeszkód stałych, informacja o ukształtowaniu terenu, w rym obiekt się porusza, jest znana jeszcze przed lotem. W przypadku dodatkowych wcześniej nieznanych przeszkód, które mogą się pojawić podczas lotu, należy użyć jednej z metod predykcji zachowania się obcego obiektu latającego. 
Strefa zakazana w opracowanym algorytmie jest traktowana jako dodatkowa stała przeszkoda o wystarczająco dużej wysokości. Natomiast maksymalna dopuszczalna wysokość lotu to jest to wysokość, którą nie należy przekroczyć podczas planowania trasy obiektu latającego. Uwzględnienie kierunku lotu obiektu latającego można dokonać różnymi sposobami. W opracowanym algorytmie użyto krzywych Dubinsa gdzie wyznacza się okręgi styczne do kursu obiektu w danych punktach. Promień tych okręgów tj. promień zakrętu, zależy od prędkości lotu oraz kąta przechylenia:

$$
r_{\min }=\frac{V^{2}}{g \cdot \operatorname{tg} \phi_{\max }}
$$

Następnie wyznacza się styczne wewnętrzne oraz zewnętrzne pomiędzy tymi okręgami. Tym podejściem otrzymujemy 4 możliwe rozwiązania. W przypadku gdy zadane punkty są o różnych wosokościach, odcinek pomiędzy punktem stycznej leżacym na pierwszym okręgu oraz punktem znajduącym się na drugim okręgu zmienia się w sposób liniowy (Rys. 1).
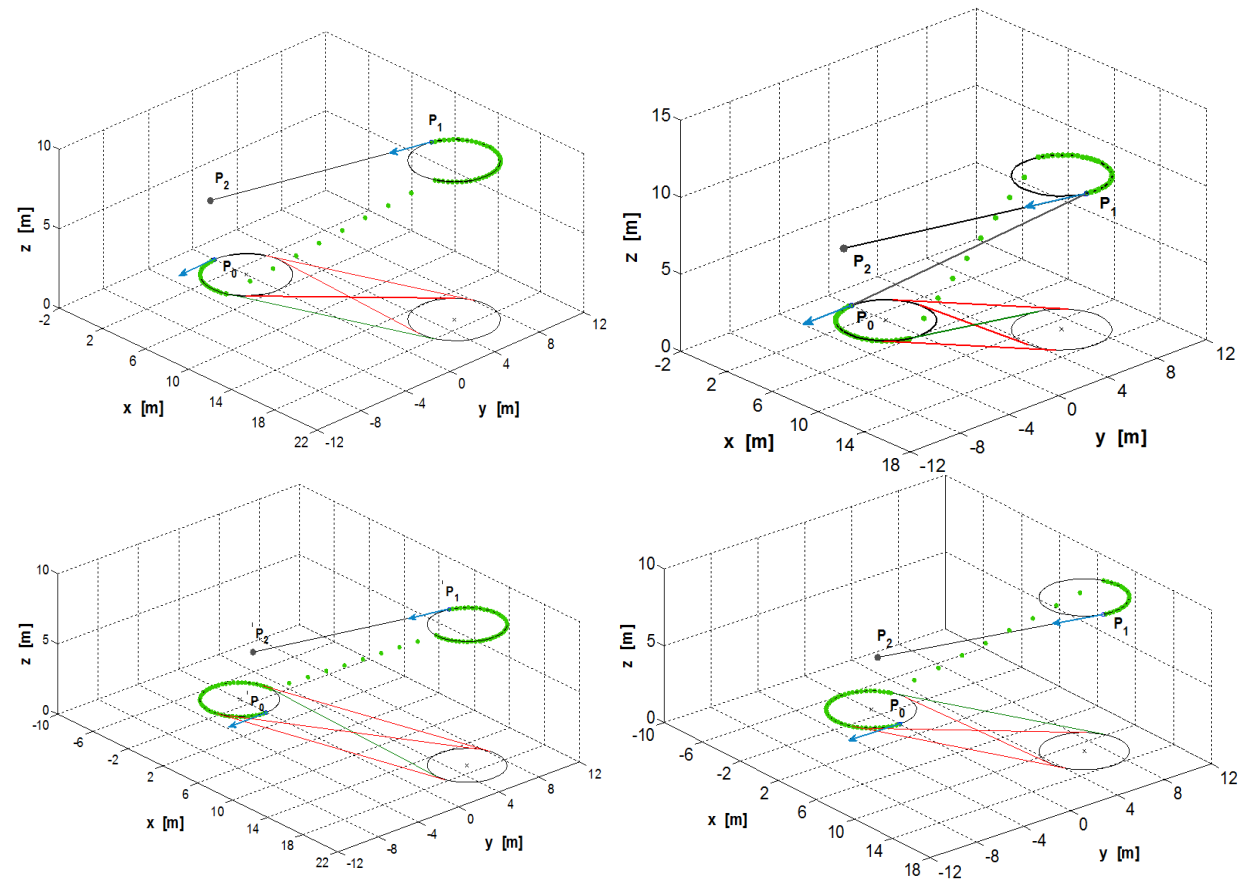

Rys. 1. Możliwe trasy pomiędzy dwoma punktami z zadanymi kierunkami lotu

Fig. 1. Possible air routes between two waypoints with given headings 


\section{Algorytm wyznaczania trasy dla BSP}

Trasa to zbiór punktów pomiędzy zadanym punktem początkowym a zadanym punktem końcowym. Punkty te wyznaczane są z uwzględnieniem ograniczeń dotyczących dynamiki obiektu latającego oraz warunków nałożonych na przestrzeń roboczą w której ten obiekt się porusza. Pojedynczą przeszkodę można ominąć lecąc powyżej jej bądź omijając ją z lewej lub prawej strony. Tych rozwiązań może być dwa w przypadku gdy lot nad przeszkodą oznaczałby przekroczenie maksymalnej dopuszczalnej wysokości lotu lub gdy taki manewr jest nie do wykonania przez statek powietrzny ze względu na maksymalną prędkość pionową lotu. W tym przypadku lotu nad przeszkodą wykorzystano algorytm opracowany w pracy [1] (Rys. 2).

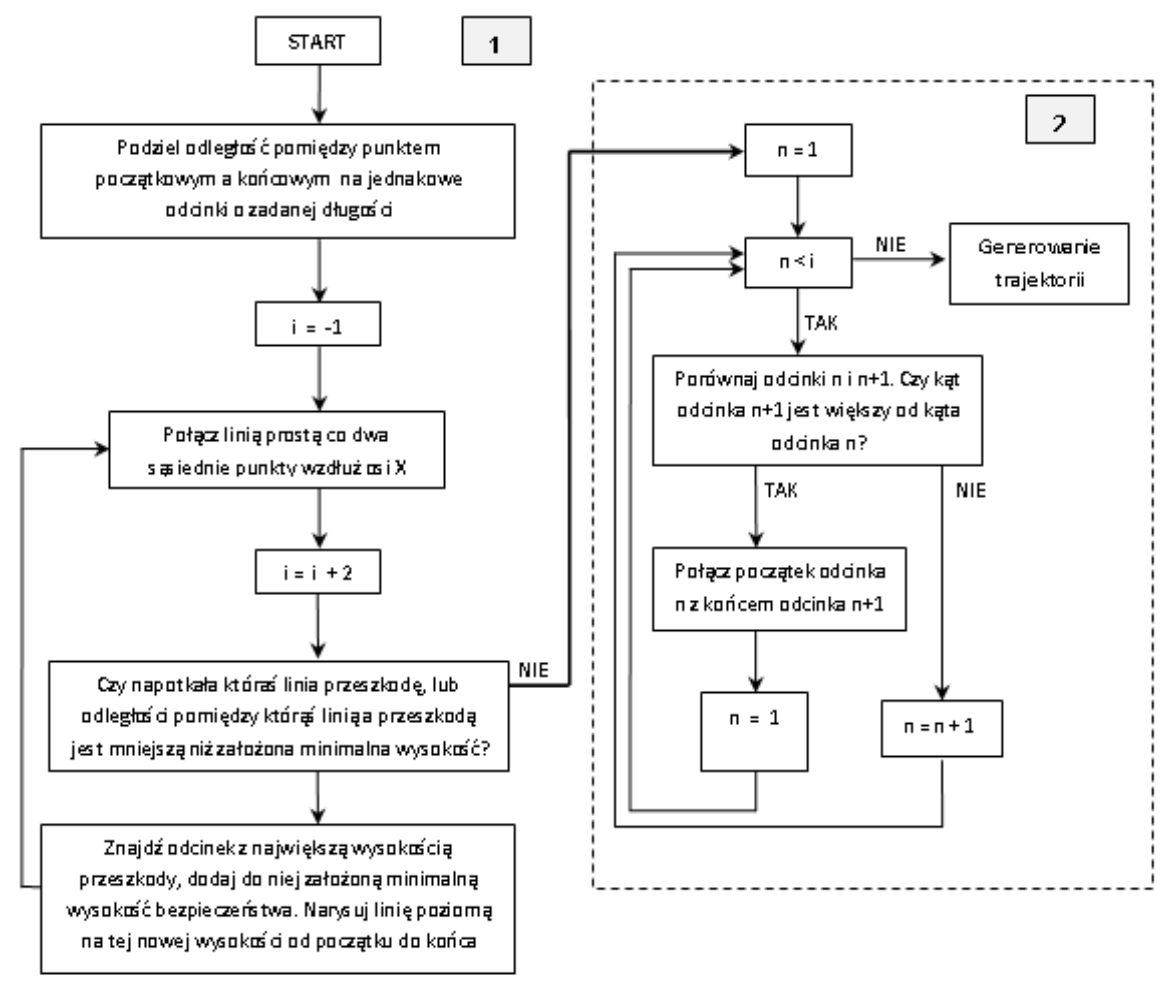

Rys. 2. Algorytm lotu nad przeszkodą [1]

Fig. 2. Algorithm for flying over an obstacle [1]

Biorąc pod uwagę kierunek lotu w punkcie początkowym oraz docelowy kierunek lotu w punkcie końcowym, oraz korzystając z wcześniej wspomnianych krzywych Dubinsa, algorytm ten jest uruchamiany dla odcinka pomiędzy punktem $\mathrm{P}_{1}$ a punktem $\mathrm{P}_{2}$ (Rys. 3). Na rysunkach 4, 5, 6, oraz 7 przedstawione zostały wszystkie możliwe trasy lotu z punktu początkowego do punktu doce- 
lowego z których można wybrać tą, która najlepiej spełnia kryterium - tutaj najkrótszą trasę (Rys. 6).

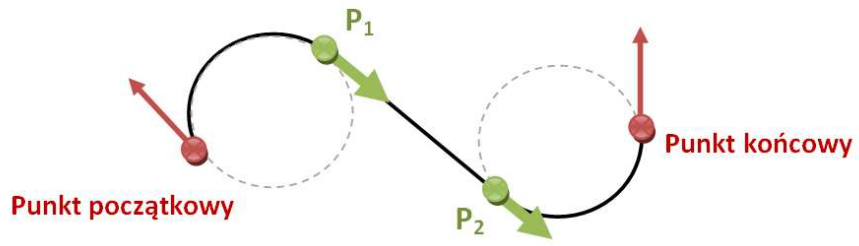

Rys. 3. Odcinek trasy dla którego wyżej przedstawiony algorytm jest używany

Fig. 3. Length of route for which the algorithm presented above is used

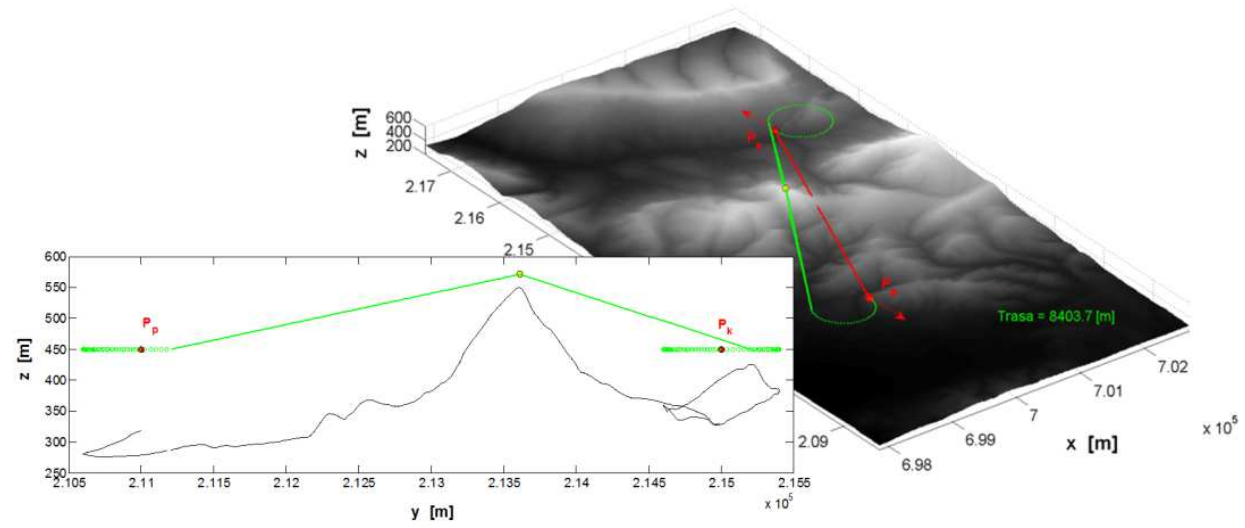

Rys. 4. Pierwsza trasa lotu pomiędzy $\mathrm{Pp}$ a $\mathrm{Pk}$

Fig. 4. First air route between $\mathrm{Pp}$ and $\mathrm{Pk}$

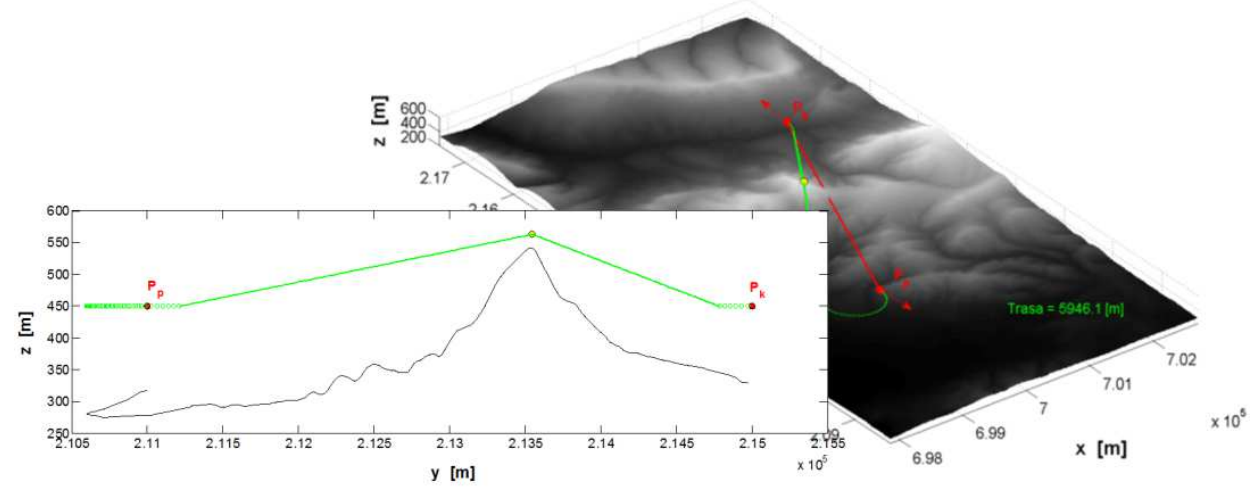

Rys. 5. Druga trasa lotu pomiędzy Pp a Pk

Fig. 5. Second air route between $\mathrm{Pp}$ and $\mathrm{Pk}$ 


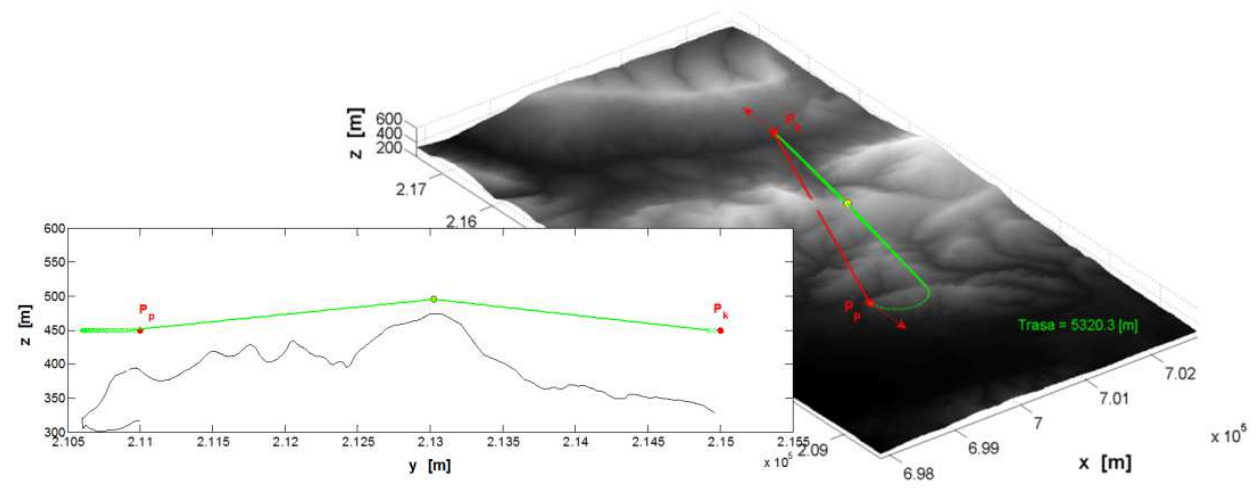

Rys. 6. Trzecia trasa lotu pomiędzy Pp a Pk

Fig. 6. Third air route between $\mathrm{Pp}$ and $\mathrm{Pk}$

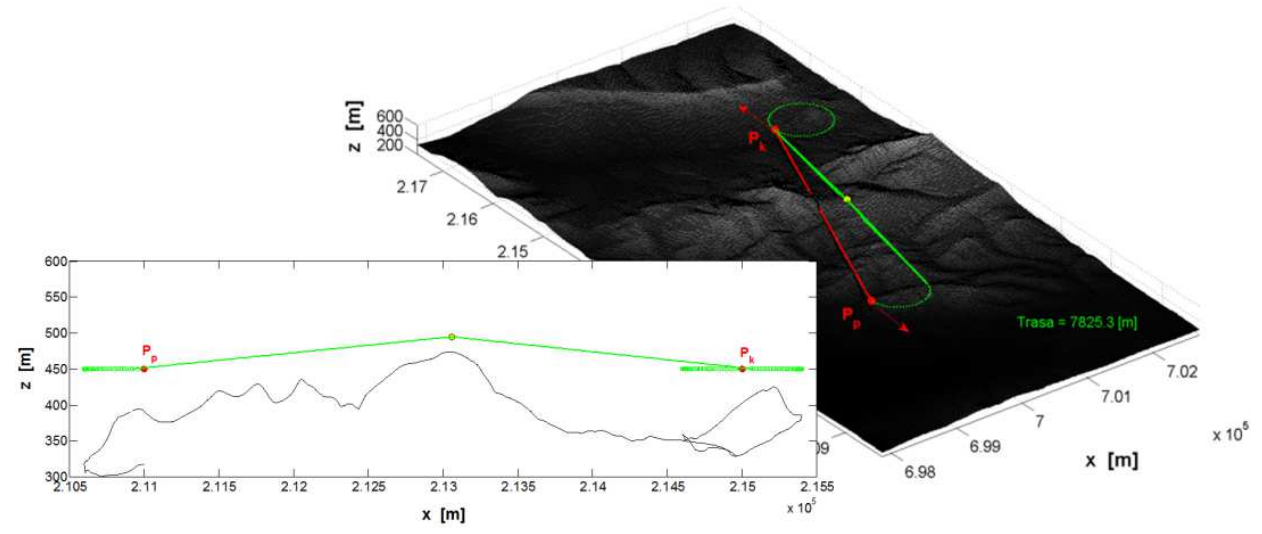

Rys. 7. Czwarta trasa lotu pomiędzy Pp a Pk

Fig. 7. Fourth air route between $\mathrm{Pp}$ and $\mathrm{Pk}$

Lot powyżej przeszkody może zostać odrzucony w przypadku gdy:

- okręgi tej ścieżki nie spełniają warunku minimalnej wysokości od terenu,

- gdy dodany punkt trasy będzie wymagał uzyskania dużego kąta toru lotu przy którym dla danej prędkości lotu prędkość pionowa przekroczy maksymalną ustaloną wartość,

- gdy współrzędna na osi z danego punktu trasy będzie większa od maksymalnej ustalonej wysokości lotu,

- lub gdy ścieżka przy wyznaczonych punktach trasy będzie przechodzić przez strefę zakazaną,

wówczas, należy wykonać manewr omijający przeszkodę z prawej lub lewej strony. Wyznaczanie trajektorii $\mathrm{w}$ ruchu bocznym wymaga jednoczesnego rozpatrywania płaszczyzny pionowej i poziomej z tego powodu, że początkowe położenie i docelowe położenie mogą być na dwóch różnych wysokościach. 
Zostanie opisany zakręt z prawej strony. Tok postępowania przy wykonaniu zakrętu omijającego przeszkodę z lewej strony jest taki sam.

Na początku wyznacza się wszystkie cztery trasy pomiędzy położeniem początkowym a położeniem docelowym, uwzględniając kurs obiektu latającego w tych punktach ( podobnie jak podczas lotu nad przeszkodą). Każda trasa składać się będzie z czterech początkowych punktów (Rys. 3). Wybiera się najkrótszą trasę dla której odcinki trasy pomiędzy pierwszym a drugim punktem oraz pomiędzy trzecim a czwartym punktem nie powodują kolizji z terenem. Zatem nasza początkowa trasa będzie trasą łączącą drugi i trzeci punkt. Następnie sprawdza się czy wszystkie punkty spełniają warunek minimalnej wysokości od terenu. Jeżeli lot po tej trasie nie spełnia warunku minimalnej wysokości nad terenem, wówczas wyznacza się miejsca w których nie spełniony jest ten warunek i wybiera się ten punkt, w którym wysokość terenu jest największa. Po określeniu tego miejsca, wyznacza się po kolei punkty: $F_{1}, F_{2}, \ldots, F_{j}$ (ze skokiem $\Delta d$ ) na linii prostopadłej do linii znajdującej się pomiędzy punktami trasy w którym dochodzi do kolizji z terenem (Rys. 8).

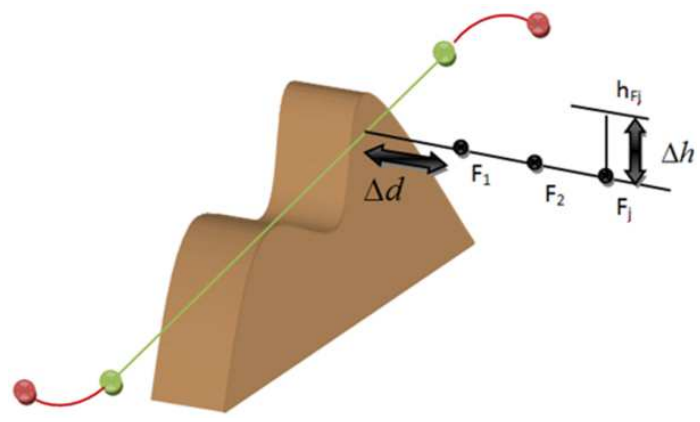

Rys. 8. Omijanie przeszkody z prawej strony

Fig. 8. Avoiding obstacle on the right side

Sprawdza się wysokość w punkcie $F_{j}$ a następnie podnosi się wysokość tego punktu tak, aby punkt znajdował się w tym miejscu nad terenem zachowując warunek bezpiecznej wysokości $\Delta h$. Jeżeli:

- wysokość tego punktu nie będzie przekraczała maksymalnego dopuszczalnego pułapu lotu,

- wykonanie wznoszenia z poprzedniego punktu nie spowoduje przekroczenia założonej maksymalnej prędkości pionowej,

- odległość od terenu będzie większa od minimalnej założonej odległości,

- kurs w tym punkcie będzie wyznaczony jako kierunek od tego punktu do punktu końcowego, jeżeli krzywe odcinki trasy leżące co dwa punktu od początku trasy aż do punktu $\mathrm{F}_{\mathrm{j}}$ nie będą powodować kolizji z terenem,

to ten punkt dodawany jest do trasy. W przeciwnym przypadku szuka się dalej: $\mathrm{F}_{j+1}, \mathrm{~F}_{j+2} \ldots$ aż znajdzie się taki punkt który spełnia powyższe warunki (Rys. 9). 


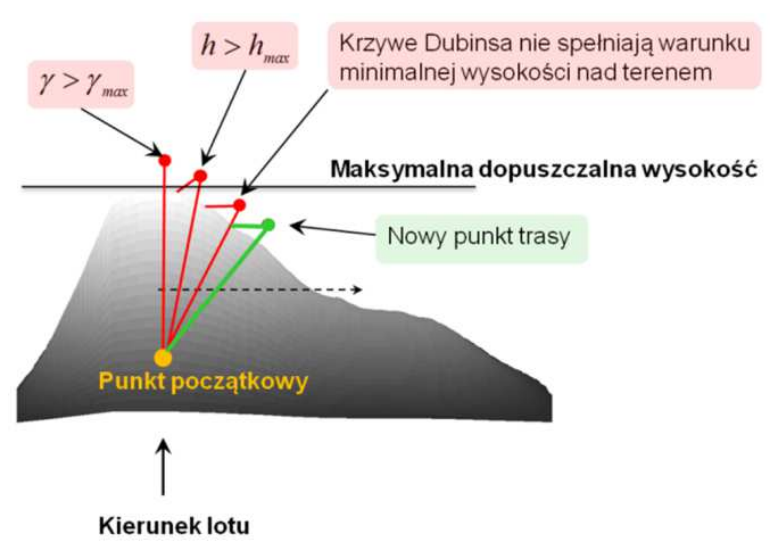

Rys. 9. Szukanie punktu trasy z prawej strony przeszkody

Fig. 9. Searching for point on the route on the right side of the obstacle

Kolejnym etapem algorytmu jest sprawdzenie prostych linii łączących co dwa punktu trasy. Jeżeli nie ma kolizji, to można powiedzieć, że mamy już szukaną trasę lotu. Jeżeli jednak nadal istnieje kolizja $\mathrm{z}$ terenem i znajduje się ona pomiędzy ostatnio wyznaczonym punktem a punktem końcowym, to powtarza się poprzednie kroki zakładając, że od tego momentu początkowym punktem jest ten nowo dodany punkt; natomiast punkt końcowy zostaje bez zmian. W przypadku gdy ta kolizja znajduje się na którymś z wcześniejszych odcinków, to na tym odcinku powtarza się te same poprzednie czynności i wyznacza się nowy punkt; z takim wyjątkiem, że końcowy punktu tego odcinka zostaje wyeliminowany $z$ trasy a jego miejsce zastępuje nowo wyznaczony punkt. Takie podejście pozwoli zmniejszyć liczbę punktów trasy. Na rysunkach (10 oraz 11) przedstawiono kolejno przykładowe trasy z zadanego punktu początkowego $\mathrm{P}_{\mathrm{p}}$, przy którym kurs obiektu wynosi $180^{\circ}$, oraz zadanego punktu końcowego $\mathrm{P}_{\mathrm{k}}$, dla którego wymagany jest kurs $0^{\circ}$; przy braku ograniczenia nałożonego na wysokość, ale przy istnieniu strefy zakazanej którą ominięto z prawej strony (Rys. 10) i z lewej strony (Rys. 11). Można zauważyć że w tym przypadku lepszym rozwiązaniem według przyjętego kryterium jest ominięcie strefy zakazanej z prawej strony.

Kolejne rysunki $(12,13)$ przedstawiają kolejno przykładowe trasy z zadanego punktu początkowego $\mathrm{P}_{\mathrm{p}}$, przy którym kurs obiektu wynosi $270^{\circ}$, oraz zadanego punktu końcowego $\mathrm{P}_{\mathrm{k}}$ dla którego wymagany jest kurs $90^{\circ}$, przy istnieniu ograniczenia nałożonego na wysokość 500 [m]; ale przy braku istnieniu strefy zakazanej. $\mathrm{Na}$ (rys. 13) przyjęto inną początkową trasę lotu niż w przypadku pokazanym na (rys. 12). Dlatego, że ta ostatnia nie spełniałaby warunku zachowania minimalnej wysokości nad terenem w przypadku części krzywolinijnych początkowej trasy. W tym przypadku lepszym wyborem jest wykonanie manewru omijania przeszkody z lewej strony. 


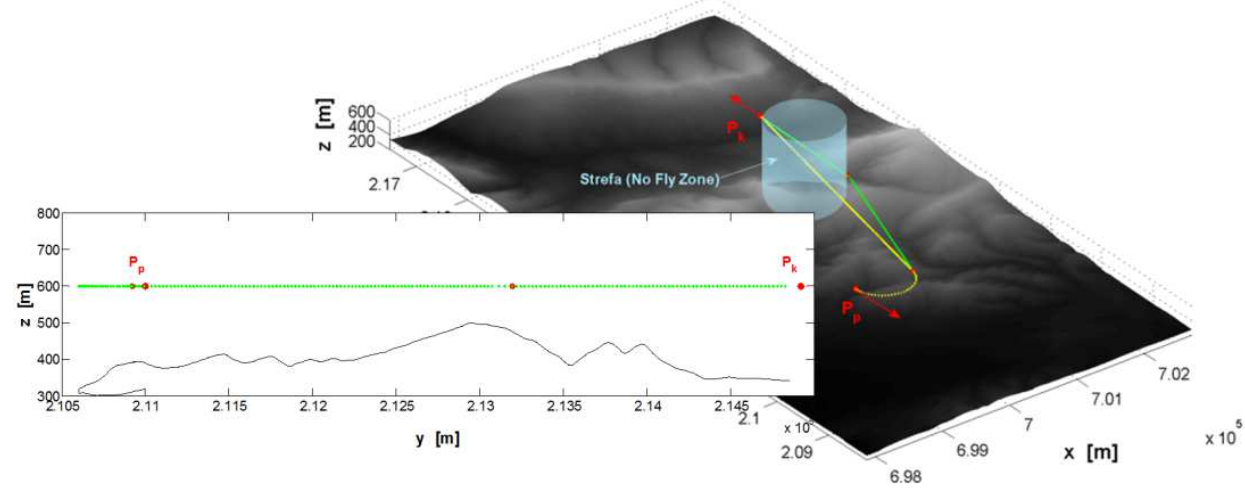

Rys. 10. Trasa omijająca strefę zakazaną z prawej strony

Fig. 10. The path avoiding no-fly zone on the right side

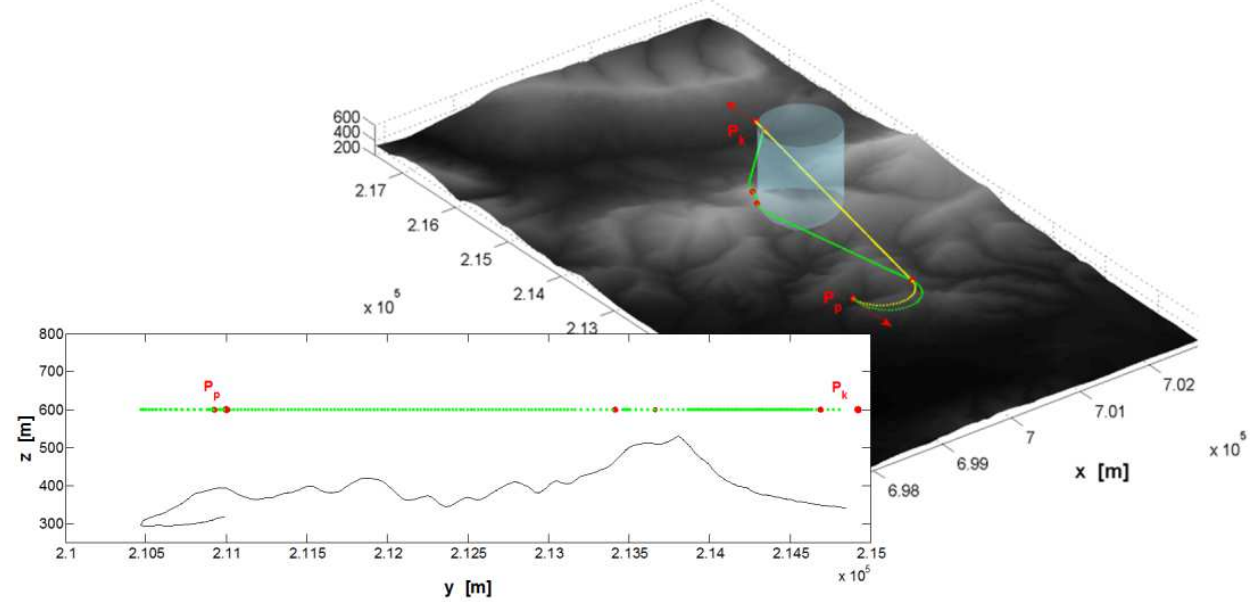

Rys. 11. Trasa omijająca strefę zakazaną z lewej strony

Fig. 11. The path avoiding no-fly zone on the left side

W przypadku większej liczby przeszkód przyjęto następującą strategię: znajdź jakąkolwiek bezkolizyjną trasę, a następnie poszukaj najlepszą. Inaczej mówiąc, na początku znajduje się punkty trasy trzech ścieżek. Pierwsza ścieżka zawiera punkty trasy pozwalające ominąć grupe przeszkód wykonując lot nad tymi przeszkodami. Następne dwie ścieżki zawierają kolejno punkty trasy omijające zbiór przeszkód z prawej lub lewej strony. Po wyznaczeniu tych ścieżek wybiera się tą, która najlepiej spełnia wcześniej założone kryterium. Po wybraniu początkowo najlepszej ścieżki, następuje poszukiwanie lepszej. Począwszy od kolejnego punktu wcześniej wyznaczonej trasy. Na rysunku 14 przedstawiono prymitywny przykład działania tej strategii. Rysunek 15 przedstawia przykład trasy z zadanego punktu początkowego $\mathrm{P}_{\mathrm{p}}$, przy którym kurs obiektu wyno- 
si $270^{\circ}$, oraz zadanego punktu końcowego $\mathrm{P}_{\mathrm{k}}$, dla którego wymagany jest kurs $270^{\circ}$.

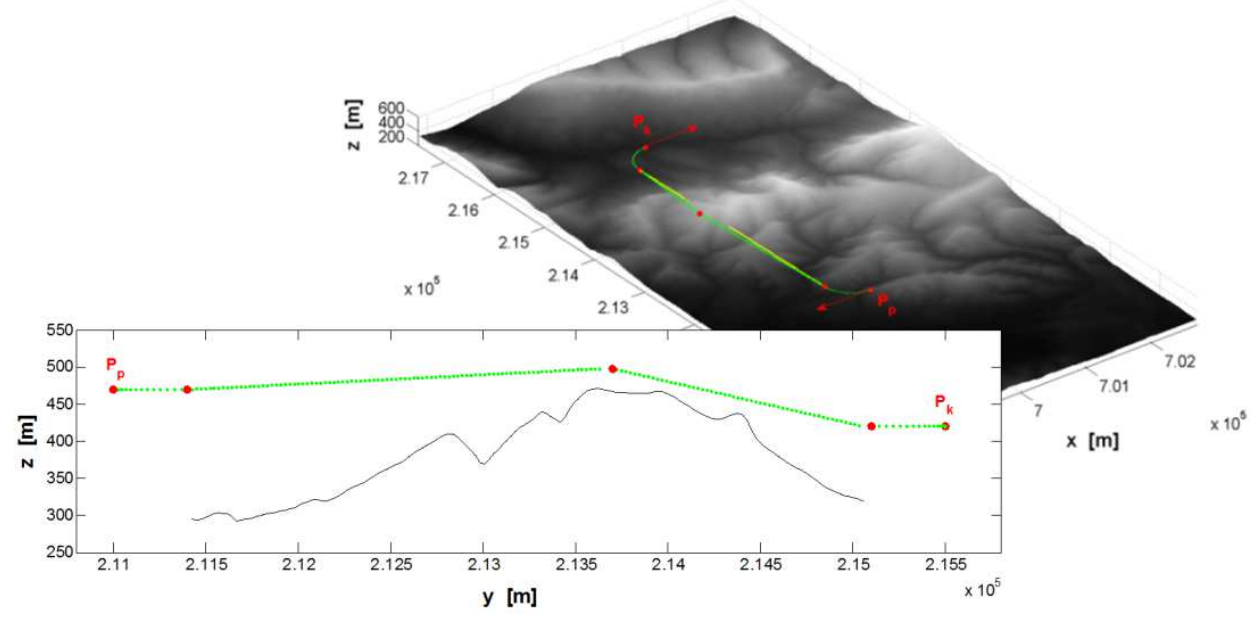

Rys. 12. Trasa omijająca przeszkodę z lewej strony

Fig. 12. Terrain obstacle avoidance on the left side

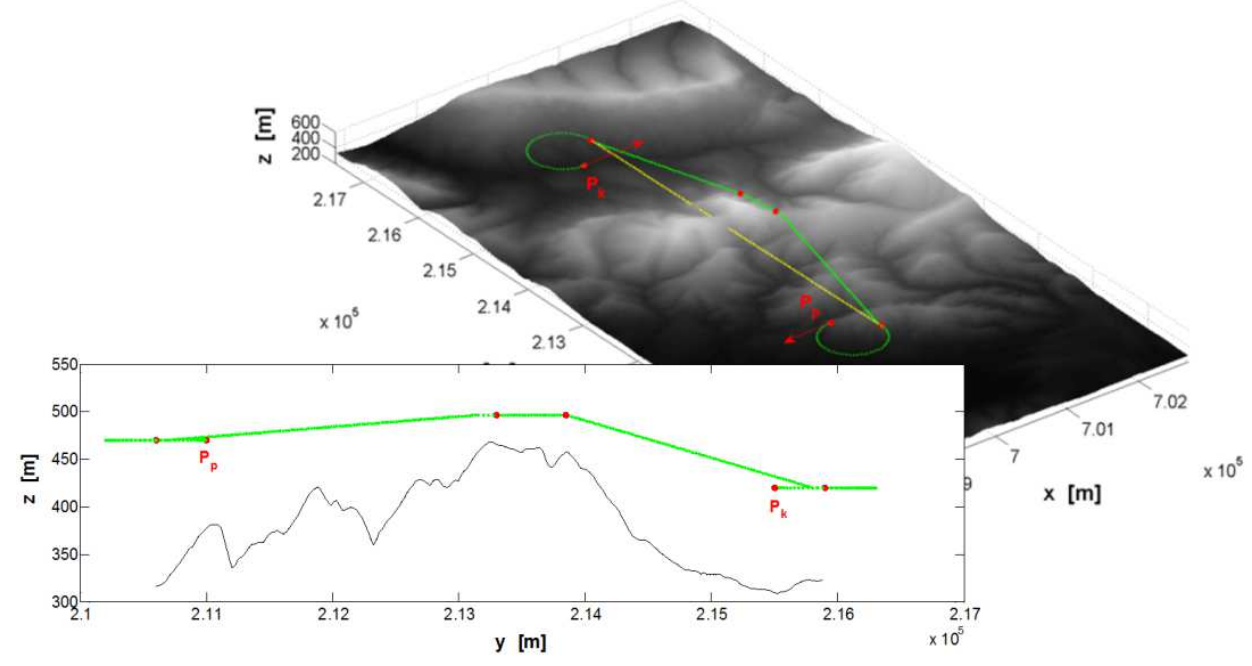

Rys. 13. Trasa omijająca przeszkodę z prawej strony

Fig. 13. Terrain obstacle avoidance on the right side

Założono maksymalną dopuszczalną wysokość równą 550 [m]. W tym przypadku na drodze przelotu istnieje przeszkoda terenowa oraz strefa zakazana. Trasa omijająca obie przeszkody z lewej strony jest lepsza niż ta, która miałaby ominąć obie przeszkody z prawej strony. Uwzględniając strategię omijania grupy przeszkód z pierwszego wyznaczonego punktu sprawdza się trasę która omi- 
ja pozostałe przeszkody z drugiej strony oraz przelatując nad tą przeszkodą. W rozpatrywanym przypadku istnienie strefy zakazanej uniemożliwia przelot nad tym obszarem terenu w którym znajduje się ta strefa; więc sprawdza się przelot z prawej strony. Na rysunku 16 przedstawiono trasę, która rozpoczyna się od pierwszego wyznaczonego punktu ale omija strefę zakazaną z prawej strony. Można zauważyć że nowo wyznaczona trasa jest lepsza (ze względu na przyjęte kryterium) niż trasa zakładająca ominięcie przeszkód i stref z lewej strony.

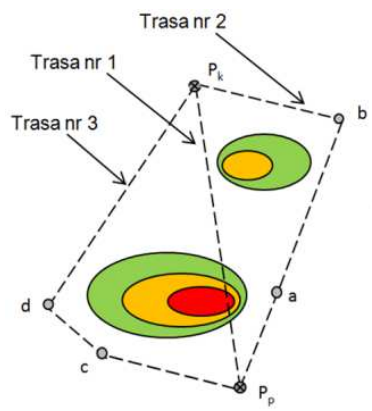

Etap 1

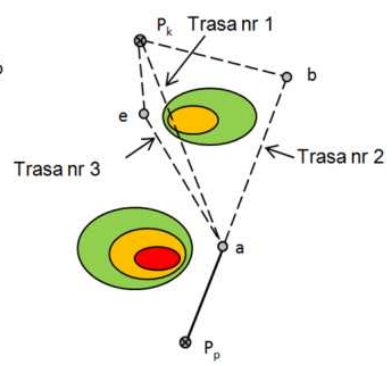

Etap 2

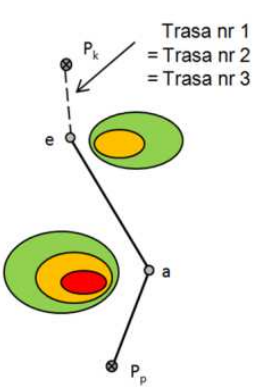

Etap 3

Rys. 14. Strategia omijania większej liczby przeszkód

Fig. 14. Multiple obstacles avoidance strategy

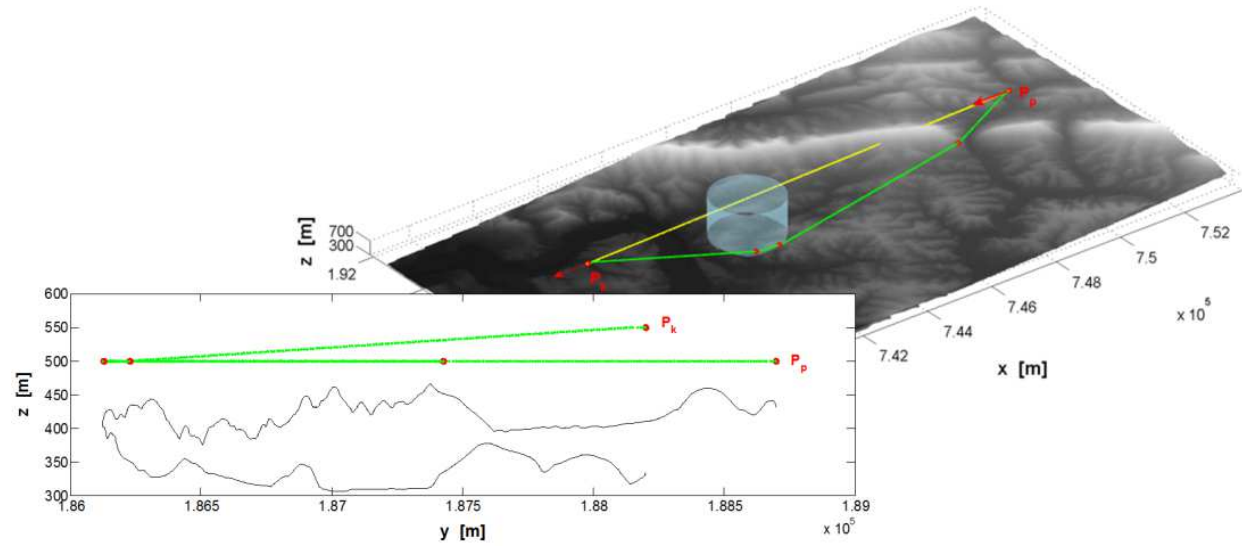

Rys. 15. Omijanie grupy przeszkód z lewej strony

Fig. 15. Multiple obstacles avoidance on the left side 


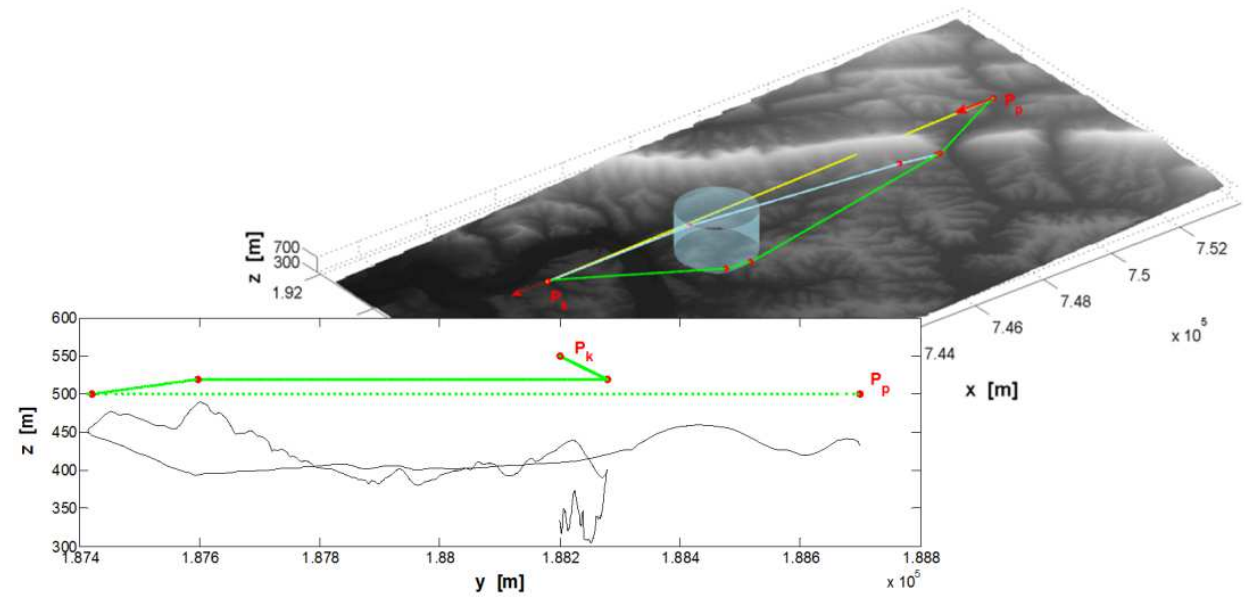

Rys. 16. Omijanie przeszkody terenowej z lewej strony a strefę zakazaną z prawej

Fig. 16. Avoiding terrain obstacle on the left side and the no-fly zone on the right side

\section{Wnioski}

W pracy przedstawiono opracowany algorytm planowania trasy bezzałogowego obiektu latającego, który uwzględnia zarówno ograniczenia nałożone przez właściwości dynamiczne tego obiektu, jak również inne ograniczenia nałożone na trasę lotu, które zostały wymienione w tym artykule. Ponadto zaproponowano metodę poszukiwania quasi-optymalnej trajektorii, w przypadku większej liczby przeszkód. Po przeprowadzeniu szeregu badań symulacyjnych można wywnioskować że czas wyznaczenia trasy za pomocą opracowanego algorytmu zależy od kilku czynników. Pierwszym atrybutem jest przedział dyskretyzacji terenu (rozmiar siatki). Im oczko tej siatki będzie mniejsze tym dokładniej można odwzorować ukształtowanie terenu ale czas obliczeń zwiększa się ponieważ będzie więcej wierzchołków do sprawdzenia. Kolejnym czynnikiem, który zasadniczo bardziej wpływa na czas obliczeń jest stopień skomplikowania obszaru, w którym obiekt latający będzie leciał. Im więcej znajdzie się w tym obszarze przeszkód (ukształtowania terenu lub stref zakazanych) oraz im więcej jest ograniczeń nałożonych na trasę przelotu, tym czas obliczeń jest większy dlatego, że algorytm musi znaleźć alternatywną trasę uwzględniającą wymienione ograniczenia oraz możliwości obiektu latającego). Mimo iż opracowany algorytm nie jest złożony obliczeniowo można by się zastanowić nad metodą grupowania przeszkód celem przyspieszenia działania tego algorytmu. Jest to jednak osobne zagadnienie które może być tematem dalszych badań. 


\section{Literatura}

[1] Basmadji F.L., Gruszecki J.: Optimal multistage fuzzy missile guidance system, Sci. Proc. Riga Technical University of Transport and Engineering. Transport. Aviation Transport, n27 (2008) 23-32.

[2] Narayan P.P., Wu P.P., Campbell D.A.: Unmanning UAVs - Addressing challenges in on-board planning and decision making, 1-st Int. Conf. Humans Operating Unmanned Systems HUMOUS'08, France 2008.

[3] Pehlivanoglu Y.V.: A new particle swarm optimization method for the path planning of UAV in 3D environment, J. Aeronautics Space Technol,. 5 (2012) 1-14.

[4] Qu Y., Zhang Y., Zhang Y.: Optimal flight path planning for UAVs in 3-D threat environment, Int. Conf. Unmanned Aircraft Systems (ICUAS), USA 2014.

[5] Seemann M., Janschek K.: RRT*-based trajectory planning for fixed wing UAVs using Bézier curves, Conf. ISR ROBOTIK, 2014.

\section{UNMANNED AERIAL VEHICLE ROUTE PLANNING IN MOUNTAINOUS TERRAIN WITH OBSTACLES}

\section{S u m m a r y}

Despite significant progress in the field of increasing the autonomy of unmanned aerial vehicles (UAVs), there are still a number of problems which needs to be solved. One of such example is the problem of autonomous path planning. In this paper, the problem of UAV path planning in mountainous terrain with obstacles has been discussed. AUAV path planning algorithm that takes into account limitations imposed by UAVs dynamics, terrain configuration, no-fly zones and the maximum allowable flight altitude has been developed. Furthermore, the method of searching for the quasi-optimal path in the case of multiple obstacles has been proposed. A series of simulation investigations to verify the correctness of developed algorithm have been carried out.

Keywords: UAV, path planning, obstacle avoidance

DOI: $10.7862 / \mathrm{rm} .2017 .01$

Otrzymano/received: 1.12 .2016

Zaakceptowano/accepted: 12.03.2017 
